\title{
“MASKING” MAKEUP: Cosmetics and Constructions of Race in Rio de Janeiro
}

\section{SAMUEL ELLIOTT NOVACICH CUNY, Graduate Center}

(iD) https:/ / orcid.org/0000-0002-9515-9887

Whenever I leave the house, it is to transform.

_Guilherme Camilo

For every sin that he committed, a stain would fleck and wreck its fairness. But he would not sin. The picture, changed or unchanged, would be to him the visible emblem of conscience.

— Oscar Wilde, The Picture of Dorian Gray

It's a hot morning in late summer, and Priscila, Fernanda, and I have just arrived at the Hotel Laghetto Stilo in Barra da Tijuca, a patchwork of gated developments crosscut with six-lane highways in Rio de Janeiro's western zone. ${ }^{1}$ We are here to attend an all-day makeup workshop with the Brazilian makeup artist Catlen Guerra. We arrive at 9:15 and check in for the event scheduled to begin at 9:00 a.m. Fernanda is excited. She works in a downtown office and is accustomed to rising early, but Priscila and I are struggling. Priscila works full-time as a makeup artist in Mangueira, a complex of favelas in Rio's northern zone. She owns a small beauty salon that serves clients most evenings. Her work keeps her up late, the space bustling with movement even into the early morning hours. Sensing our fatigue, Fernanda asks me to save their places in line and takes her best friend, 
Priscila, in search of coffee. Both women identify as negra, or Black, although Fernanda's complexion is slightly darker than Priscila's. As amateur and professional makeup artists, respectively, they routinely scrutinize the skin colors of those around them. They also take care to inspect dermal qualities like saturation and subtones, oiliness and wrinkles, though not always, as I will soon explain, in ways they approach as having to do directly with race. While waiting, I meet three more workshop participants - Manuela, Liliane, and Karina. We exchange introductions and Fernanda and Priscila return, empty-handed, a few minutes later.

By 9:45 a.m. we are seated, and the lights dim. Smooth jazz plays over a PA system, and a crowd of nearly 150 people rumbles with anticipation as a tenor saxophonist enters the room. A white, platinum blond makeup artist (maquiador), and his model, a young Black woman wearing a long, tightly fitting dress, trail the saxophonist. Both wave and snap selfies before taking the stage. Under a spotlight, the maquiador works quickly on his subject's skin, applying foundation, concealer, contour, and highlights before moving on to her eyes. A camera feed projects her face onto two enormous screens that flank the stage. He draws sharp "cat eyes" on her face, a trail of eyeliner extending back, up, and away. The saxophonist aims his horn directly at the two and mimics a snake-charmer coaxing into existence what we in the crowd watch unfolding on stage. The maquiador reshapes his model's hair, transforming her Afro into a more punk, "faux hawk" hairdo. He cuts off the sleeves and bottom length of her dress, pulling down the black fabric to reveal her shoulders, before she sits for the final adjustments to her face. The music changes. Lady Gaga's "Shallow" plays on repeat, the crescendo of music and makeover not quite in unison. Satisfied with his work, the maquiador, Guilherme Camilo, motions for his model to rise to thunderous applause as the music lowers and the maquiador speaks: "Toda vez que eu saio de vida, é pra transformer . . . a maquiagem transformou minha vida, e pode transformar a vida de todas" (Whenever I leave the house [to work], it's to transform . . . makeup transformed my life, and it can transform the lives of everyone).

Makeup alters the surfaces of bodies. This much is obvious. It is one of several technologies that accentuates the fluidity of the skin and, specifically, the ephemerality of the face. But the skin already exists in a state of constant becoming. Not only does it change with one's environment - sunburns, tans, and dirt lend testimony to this - but with one's emotional state, as we blush, take on stress wrinkles, or go pale with fear (Jablonski 2006). And the pre-made-up face provides a particularly fluid medium, one further unsettled with makeup. For this reason, makeup is critical to local understandings of transformation and foundational to 
constructions of race in Brazil today. But makeup does not simply transform a person by altering their face. Rather, applications of makeup destabilize the fragile hermeneutics that tie insides to outsides, essences and souls to physical appearance. And in doing so, these aesthetic practices allow for novel productions of race that question the very foundations on which race in Brazil has historically been built.

In spite of their mutability, faces are often regarded — at least within Western imaginations - as fixed and authentic. Meanwhile, it is the mask that is more typically associated with concealment and deceit (Belting 2017). Claude Lévi-Strauss (1972) famously rejected this limited understanding of the mask, asserting in his analysis of Caduveo face painting that indigenous decoration actually constituted, rather than obscured, personhood, an argument later echoed by Eduardo Viveiros de Castro (1998) with respect to feathers and clothing. Hans Belting (2017, 90) extends the critique on limited understandings of faces and masks further, asserting, "a face is not static. It looks backward to the path it has already traversed as well as predicting the mask that it will become in death." But faces and masks do not exist in opposition. Rather, the face is a historical object consisting of infinite masks that alternatively show and conceal our putatively authentic selves. Belting's analysis - in keeping with Gilles Deleuze and Félix Guattari’s (1987) characterization of the face as both window to the soul and screen of representation-points, in a sense, to the multivalent semiotics of facial signs. These signs may point inward but, just as often, facial signs are refracted outward (Siegel 1999). Indeed, such outward-pointing signs underpin Andrew Strathern's (1975) arguments regarding shame in Papua New Guinea, where he describes the emotion as living visibly on the skin. Shame manifests on the skin where it can be seen, and rather than reflecting emotions found deep within, it points to a relationship with the social world beyond the body. As Strathern's (1975, 350) primary informant explains, and in so doing negates any index to bodily insides, “"we say we are pipil [ashamed] . . . but inside ourselves we may be feeling quite good. . . . It is only when other people are there that we actually feel ashamed about it." In pointing outward, signs of the body - whether they are signs of shame or makeup applied to the face-bond with new aesthetic sensibilities (Rancière 2004) and join discursive constructions that paint the picture of "who a person is" (Benson 2008). This underscores the important parallels between the practices of masking and making up, as well as the transformative components to each. And to that end, the double nature of masking, or its potential to both cover and reveal, applies just as readily to the world of makeup. In fact, in Rio, clients often refer to makeup application in ambiguous and apparently contradictory terms, as both covering blemishes and 
smoothing out wrinkles — and as revealing true selves. This double nature of making up factors critically in contemporary understandings of race in Brazil, where, as elsewhere, racial logics are founded on "evidence" located both on the surface of the body and hidden deep within.

Despite ambiguities that extend far beyond the salon, the face and bodily surface have long been looked to as indexes, or windows, to internal qualities like essence and moral character, most notoriously in pseudoscientific and overtly racist turn-of-the-century studies in phrenology (Galton 1879; Lombroso and Lombroso 1911) and their applications on imperial frontiers (Poole 1997; Stoler 2002). The paintings of Jean-Baptiste Debret, for example, famed for documenting everyday life in nineteenth-century Brazil, include studies of indigenous and enslaved Afro-Brazilians and pay careful attention to phenotype and color. Debret's work predates continental phrenology, and yet it rests within an enduring logic that ties racial essences to outward physical appearance. Although long disproven and rejected as racist by social scientists, such interpretive logics live on in innumerable iterations, from mug shots (Sekula 1986; Strassler 2010) to contemporary constructions of race around the world (Collins 2011). These interpretive logics form what Daniel Miller calls depth ontology, the pervasive Western "assumption that being — what we truly are — is located deep inside ourselves and is in direct opposition to the surface" (Miller 2010, 16). And while such ontology informs the aesthetic practice of some makeup artists in Rio, it is just as often disregarded and even rejected by others.

As I will illustrate in the pages to come, there is disagreement between makeup artists and a tension exists throughout the industry between an aesthetic sensibility that focuses on beautification and another that prizes transformation. While beautification favors supposedly natural looks, it does so based on the belief that the surface of the body accurately reflects who we really are, inside. Beautification thus aims to match those truths, the visible but elusive surface of the skin and the invisible but stable interior. Makeup artists and enthusiasts who relish transformative aesthetics, on the other hand, seem to do so based on the belief that appearance is itself foundational to personhood, and that in fact all appearance constitutes a mask. Miller $(2010,13)$ takes this latter approach to the extreme in asserting: "If you keep peeling off our layers you find-absolutely nothing left. There is no true inner self. We are not represented by clothes, because if we remove our clothes there isn't an inner core. The clothes were not superficial, they actually were what made us what we think we are." Similarly, Webb Keane (2005) has argued that signs and clothing do not simply reflect meaning but, rather, pro- 
duce it through engagement with the social and material world. The aesthetic logics and varied constructions of race described in this article are thus linked in critical ways to assumptions about the reality of being, and in particular, to the relationships between surfaces, appearance, truth, and depth. These logics also inform, at least partially, the complex relationship between beauty and subjectivity in Rio de Janeiro's northern suburbs.

One important resource for thinking through the aesthetic ambiguities of faces, makeup, and masks and their relations to interiority comes not by way of the social sciences, but, instead, from Oscar Wilde. In Wilde's The Portrait of Dorian Gray, the title character, a young socialite, has a portrait commissioned, and upon seeing his image, confronts for the first time the existential dread of aging and mortality. Wilde writes:

And now, as he stood gazing at the shadow of his own loveliness, the full reality of the description flashed across him. Yes, there would be a day when his face would be wrinkled and wizen, his eyes dim and colorless, the grace of his figure broken and deformed. . . . "How sad it is!" murmured Dorian Gray, with his eyes still fixed upon his own portrait. "How sad it is! I shall grow old, and horrid, and dreadful. But this picture will remain always young. It will never be older than this particular day of June. . . . If it was only the other way! If it was I who were to be always young, and the picture that were to grow old!" (Wilde 1962 [1890], 33)

As the story progresses, Dorian's wish is fulfilled, and the portrait ages, taking on the physical blemishes of every sin and immoral act committed, while he remains young and beautiful. It is no coincidence that Wilde penned his masterpiece at the height of phrenological debates that waged in Europe and the Americas at the close of the century, as a clear logic throughout links bodily insides to outward physical appearance. And yet the twist in this logic is what drives the story forward - the fact that this link has been momentarily interrupted and transposed. The "true" outward appearance of Dorian Gray, his screen of representation and the window to his soul, has been lifted from his body and projected onto a foreign surface - a canvas - freeing him to live with reckless abandon without fear that his face betray his sins. ${ }^{2}$

Residents of Rio de Janeiro's working-class, peripheral neighborhoods also disrupt the interpretive relationship between physical appearance and interiority. They do so through another form of portraiture, by manipulating the surface of 
the body with color. In Wildean fashion, makeup artists and their clients de-link the surface of the body from notions of interiority, fracturing, if not entirely destroying, this interpretive relationship. Indeed, my ethnographic data will show that at times, makeup artists and their clients interpreted their own bodily aesthetics — skin color, hair, noses, eyes, and ears - in relation to racial identity and the experience of living as negras in contemporary Brazil. But just as often, I witnessed an estrangement of these aesthetics from constructions of race, and more paradoxically, I heard suggestions from my interlocutors that these aesthetic details had little to do with race at all.

This article will demonstrate how the surface of the body in favelas of Rio de Janeiro - where color and phenotype literally and metonymically reside, respectively_ can be aesthetically and conceptually decoupled from constructions of race. This conceptual decoupling proves particularly salient in Brazil, where discourses on race depend in critical ways on the visibility of signs, such as color and phenotype, rather than on invisible - yet ostensibly knowable - genealogical cues (Nogueira 2007 [1954]; Harris and Kottak 1963; Guimarães 2002). This text will show how signs on the body oscillate between pointing to categorical constructions of race, on the one hand, and pointing to beauty, sex, and desire, on the other. Yet drawing attention to this semiotic oscillation does not suggest that race, beauty, sex, and desire are separate constructions. These relational terms indeed intersect in both productive and detrimental ways. In fact, the play in these signs between indexical overlap and divergence underlines a basic premise of sign theory more generally — signs are typically polysemous, signifying different things to different people in dialogue with their objects, in accordance with different contexts, and in relation to the materiality of the sign vehicle (Peirce 1955). In Rio today, the signs produced by manipulating the bodily surface with makeup do not always fit neatly into established racial ideologies. As a result, makeup - as an indexical sign that joins with and alters the material surface of the body - may foster ambiguity and even apparent contradiction when it comes to local constructions of race. As I will argue, makeup application on Rio's periphery often makes for a nondiscursive aesthetic practice, one that, rather than responding directly to existent discourses about race, gender, or sex, focuses instead on the phenomenological experience of transformation - enacted on the surface of the body - and the sensuous desire to be beautiful. And while the open-ended nature of semiotic play creates the conditions for new aesthetic possibilities and novel forms of subject formation, it also points, on a more somber note, to the persistence and malleability of race and racisms in Brazil today. 


\section{TRANSFORMATION AND BEAUTIFICATION}

At the workshop, Guilherme Camilo introduces himself by focusing on the transformative power of makeup. He steeps his presentation in metaphor, which implicitly links his aesthetic and material transformations to social and psychological effects. As he demonstrates a technique for applying eye shadow, Camilo also passionately promotes the affective power of makeup in building greater self-esteem. In his study of plastic surgery in Rio, Alexander Edmonds encountered a similar discourse among plastic surgeons, several of whom described themselves as psychiatrists working on the body to get at the soul (Edmonds 2010). Edmonds's plastic surgeons, similar to makeup artists like Camilo, stitch together a relationship between the bodily surface and the psychological self. And yet, in neither case does the surface of the body represent a priori inner truth. Rather, the body is worked on to access and manipulate emotions believed to reside deep within. ${ }^{3}$ "Whenever I leave the house, it is to transform . . ." - Camilo is thus speaking on two levels here, and in fact refers to spiritual shifts in both artist and client. He tells a story of how makeup changed his life — a narrative that fits well with a workshop focused as much on entrepreneurship as on aesthetics - and slips imperceptibly between descriptions of the physical and spiritual as he recounts transformations in and of his clients.

Yet others push back against artists like Camilo, and argue that makeup should not transform anyone at all. They argue that makeup should instead focus on embelezamento, the beautification of what already is. And yet, the implied constant in this process of beautification remains unclear. Is it the general shape of the face? Material qualities of the skin? Imagined internal essences? Months later, back in her studio, I'm still searching for clarification on this point, and I ask Priscila to explain. ${ }^{4}$ She responds that makeup artists who focus on beautification craft their makeup in harmony with the face underneath, rather than in contrast to it. Still confused, I push back: "But isn't all makeup transformative, in that each layer is different from the layer underneath?" As I understood it, makeup changes one's physical appearance, because anything additive, pigments and opaque layers not there before, must bring change. "But you aren't narrowing the nose or trying to change the face," she says. Priscila then shows me a photo of a model on her phone to prove her point. The girl is young and has vitiligo, but rather than using tones that camouflage the vitiligo on her skin, she is wearing makeup that preserves the mottled pigmentation of her face. There is no concealer to cover or homogenize variations in her skin. It is beautiful and jarring to see the girl with vitiligo wearing teal blue eye shadow and red lipstick. "This is embelezamento. She isn't trying to 
hide who she is. She has vitiligo." As Priscila explains, the most essential qualities of personhood, those that make the girl with vitiligo who she is, are reflected, at least in this moment, on the surface of the skin.

After lunch, I find Manuela back in the event space and ask her about the workshop. She explains that she previously worked in television, doing makeup for actors and journalists for Globo (a media empire that includes Brazil's largest television network), but stopped to have kids. She lives in the wealthy neighborhood of Gávea, and now that her children are older, she has returned to the makeup industry. The workshop presents an opportunity to become acquainted with contemporary trends. In her early to mid-forties, Manuela is tall and white with bluish-green eyes. She admits to being challenged by social media platforms like Instagram, and I notice later that she has far fewer followers than her workshop peers. She also confesses to disliking the styles on display at the workshop, which she thinks are "too strong." She lowers her voice while describing the makeup as "too heavy" and asserts — so as to highlight their excess — that it was "men doing drag" who had originally developed the contouring techniques now taught on stage. ${ }^{5}$ "Think about it," she says, "women are already women; we don't need to contour our faces beyond what they already are."

Manuela takes issue with the idea of transformation, bringing our conversation back to the spectacle that opened the workshop. Although a subsequent presenter seemed to push back against Camilo's discourse of transformation, highlighting "embelezamento em vez de transformação" (beautification rather than transformation), Manuela did not seem convinced. "Yes, but she still transformed her model." She goes on to assert that she likes to practice a simpler form of makeup that uses less contour. And she certainly would not engage in a makeup practice designed to narrow the nose, a technique used repeatedly, I would later discover, back at Priscila's salon. Manuela is careful not to mention race directly, perhaps because of her own discomfort or a vestige of generational politeness, though it remains just below the surface of our conversation (Sheriff 2001). She summarizes her aesthetic preferences by saying that she values a "natural look," but laments that despite her own tastes, she still feels a pressure to respond to her clients' desires for bolder styles if she is to reignite her career successfully.

\section{"MASKING"}

Two months later I met up again with Manuela at a shopping center in Ipanema, where she further clarified her aesthetic preferences: 
I don't like masking makeup. I know that it's in style, it's all over the Internet these days, but it isn't the kind of makeup that gets my respect. Remember that day of the workshop, I told you this, and you asked me "so why are you here?" Because that workshop was 100 percent masking makeup. . . . I call it a mask, because a person enters one way and leaves a totally different person ... she changes. It changes these young girls, beautiful girls. [Referring to one of the models that had been on the workshop stage.] The makeup is erasing her youth, erasing it! She had a beautiful face . . . she didn't have to layer on that covering of makeup.

For Manuela, transformation in its most extreme iteration seems to concern moving between established lines of difference, oscillating between categories of race, gender, and, as indicated here, even age. With each transformation, the surface of the body is altered in contrast to the more essential qualities of personhood that are both unchanging and assumed to exist deep inside. In the example that she gives at the workshop, and repeats again in our meeting months later, drag queens transform themselves by using contour to make their faces more feminine. For Manuela and others, transformation implies only superficial movement between — or beyond — fixed sets like old and young, man and woman, and Black and white.

It is remarkable that Manuela codes these cosmetic transformations, these unexpected "lines of flight" from habitual aesthetic categories, as "masking" (Deleuze and Guattari 1987). Perhaps "masking makeup" transcends the immanent, material transformations of daily life (Belting 2017) — the perpetual movement of the face, the appearance of dirt and sweat, sunburns and muscle fatigue, especially in an environment like Rio - and instead marks a process of deterritorialization, or as Manuel DeLanda (2002) has described it, ascendance to the virtual. Indeed for some, "masking makeup" seems to push uncomfortably at the margins of color, like the intentionally blurred boundaries of an impressionist painting (Kalba 2017), distorting established aesthetic styles in perfect metonymic relation to fixed categories of personhood. Indeed, in pushing at the margins of color, masking makeup also quite literally draws unmade-up parts of the head and body into new relation with the made-up face. By creating a "mask" of makeup, artists alter without touching that which is already there, transforming even untouched parts of the body that lie beyond the boundaries of synthetic color. Transformation thus extends to the body that contextualizes the obviously made-up skin - the hair, the ears and neck, the person as a whole, even in the absence of makeup. But to refer 
to these aesthetic transformations as "masking," or rather, to regard such transformations as aesthetically problematic, also implies a particular kind of engagement with the world, a "depth ontology" in which the relationship between surface and depth is stable and knowable, and one to which Priscila and her peers do not always subscribe. Moreover, such a negative reaction to masking makeup seems to miss the degree to which the transformative process - for maquiadoras like Priscila - is in fact made to be deliberately obvious.

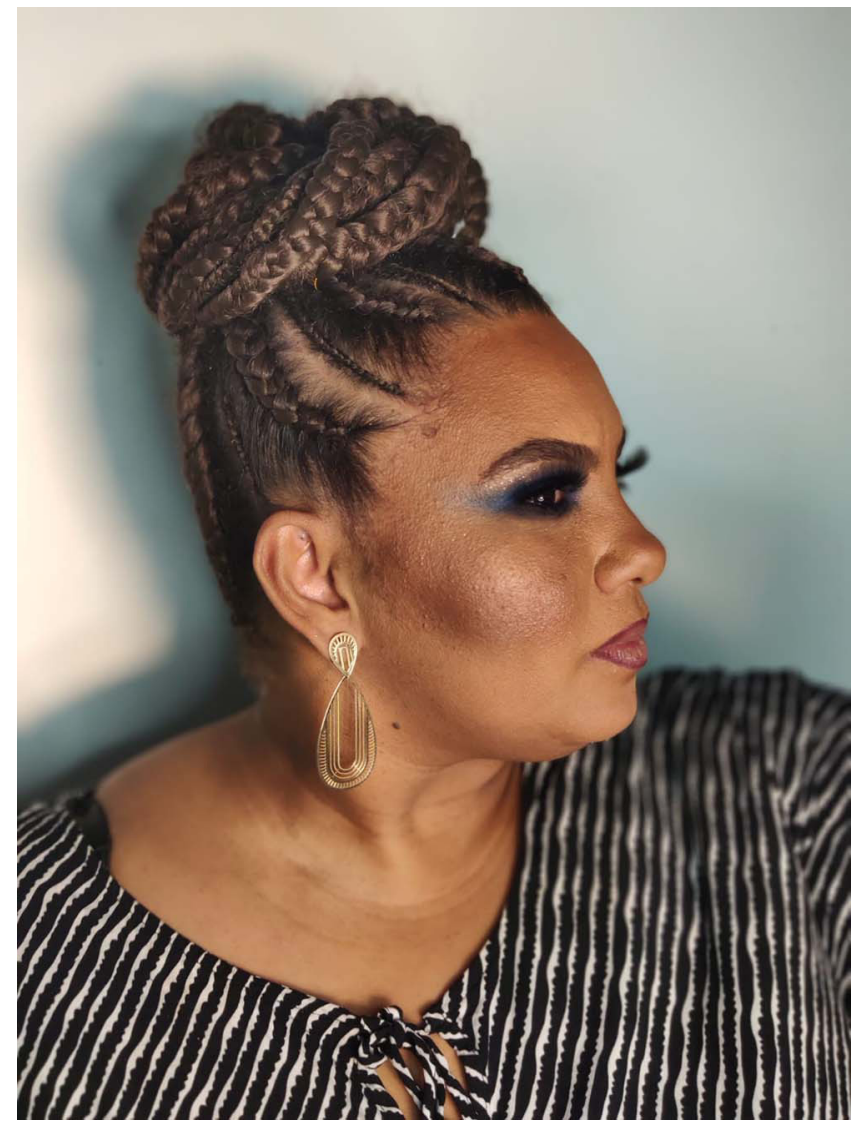

Figure 1. Priscila in her makeup studio. Photo by Samuel Elliott Novacich.

In discussing the semiotics of masking, Donald Pollock (1995) has pointed out that masks are icons of identity that conceal or modify signs conventionally associated with the self. Masks may emphasize eyes, noses, or even ears. When put on, masks also become indexes of identity transformation. For example, eye coverings worn at masquerade balls signal disguise, since in much of the West eyes 
are a conventionalized sign of identity. However, in practice, these masks fail to conceal much at all. ${ }^{6}$ And so while a mask constitutes an icon of identity in that it mimics or conceals a particular object, in this case the eyes, it also performs the more important indexical function of pointing to the process of identity transformation itself by leaving bare what are ostensibly enduring, material features of the face (Peirce 1955; Pollock 1995). It is the border of the mask, those opaque edges touching the face, that proves so critical to transformation. To wear a mask is thus to point self-consciously and unabashedly to identity transformation, without necessarily hiding the process at all. The makeup that Manuela and others dislike for being overtly transformative may perform a similar function, and indeed studies of drag have long pointed to this metafunction of makeup (Goldsby 1993). While maquiadoras like Manuela use makeup techniques that strive to erase their own existence, artists like Priscila focus on increasingly self-referential styles. Indeed, rather than "blending in" to the bodies that frame the face, the made-up faces of Priscila's clients often stand in marked contrast to their necks, ears, and torsos. And Priscila's clients, examining themselves in the mirror with bold, eye-catching makeup, oftentimes exclaim, "I woke up like this!" in a playfully sarcastic and perhaps even mocking reference to the "natural" or "clean" makeup styles favored by artists like Manuela. ${ }^{7}$ And this metacommentary-ironically relishing in the absurd - perfectly complements and even advances the process of material transformation. Keeping this in mind, each application of makeup compels new sets of questions, such as, Why emphasize aging? Why point to gender transformation? What statements are being made about race?

As makeup artists like Priscila add layers of pigment to the skin, they problematize the relationship between that which is thought of as natural and existential states like realness and authenticity. And while clients may relish in the irony of exclaiming, "I woke up like this," there is also a sincerity behind the aesthetic logics that make these makeup styles possible and, moreover, desirable. In the Brazilian state of Bahia, some 750 miles north of Rio de Janeiro, Mattijs Van de Port (2012) has problematized the association between "natural" and "genuine," and pointed to alternative "registers of sense-making" that go beyond the "natural" to answer the question of what is "real." Van de Port $(2012,865)$ looks first at "camp," which pushes viewers "to unmask the natural and expose it as yet another form of make-believe" (see also Sontag 1966) and then to the Baroque, which points similarly to the "concocted-ness" of the human-made world (Collins 2015) in much the same way that the metacommentary above points to the concocted-ness of "natural looks." In working with drag performers in Bahia, Van de 
Port (2012, 870) cites another register of sense-making that he calls montado, or, literally, "assembled," again suggesting the "made-up-ness" of makeup, wigs, and over-the-top costume. Here the "the body in montado aesthetics is indexical of ecstasy, lust, orgasm, experiences of bliss" (Van de Port 2012, 873). These registers are not separate, but rather different modalities "of one and the same aesthetic impulse: to reveal, rather than veil, the breaches and impossibilities of the cultural orders that reign over our lives" (Van de Port 2012, 875). That is to say, while there are aesthetic registers that make sense of and order reality, hermeneutics that naturalize and fix the world around us, there are also impulses to point out the shadowy distortions in such logics, aesthetic impulses that put pressure on constructions of gender, race, and sexuality.

The tensions between appearance and reality, exemplified by blurred categories of race and personhood, and attempts to make those categories clear are endemic to social and political life in modern Brazil. While ambiguous, perhaps, these tensions also hinge on a critical aesthetic dynamic between what is visible and that which remains hidden from view (Stoler 1997). Just as the edge of the mask draws in and transforms the body that extends beyond its reach, so, too, does the made-up surface of the face draw in and reconstruct what remains hidden beyond the skin, or indeed, below it. And yet, these borders between mask and body, and between surface and depth, become increasingly nebulous with each transformation (Collins 2015). Indeed, the ambiguity produced through transformation may in fact be a desired effect, one similar to Baroque aesthetics, for example, known for pulling in viewers and muddling the distinction between subject and object. In a related formulation, Fenella Cannell (1999) argues that pageant contestants in the Philippines revere the aesthetics of transformation itself in ways that shape both their performances and understandings of beauty. These aesthetic impulses do not deny the realness of the individual, whether drag queens in Bahia, pageant queens in the Philippines, or makeup artists and clients in Rio. Rather, these aesthetic registers question the assumption of the "real" as stable, knowable, or located in a consistent place. These aesthetics revel in evolutions and ambiguities, and in the case of beauty on the periphery of Rio, they also point to the mutability of racial logics that connect bodily outsides to ideas about interiority and essence.

\section{MAKING UP RACE}

One makeup practice widely associated with transformation is a technique to narrow the nose. Makeup artists routinely use delicate applications of light and shadow to afinar, or taper, the nose of their clients, especially those of Afro-Bra- 
zilian descent. At the workshop, each presenter treads lightly when coming to the nose, and though each has worked almost exclusively with white models, they have all hinted at—without commenting directly on-race. "There are no standards when it comes to the nose, or rather, there are many standards. . . I have my own standard ... " one presenter says, trailing off as she speaks somewhat uncomfortably, before moving on. The audience is far more diverse than the presenters on stage, and I notice quick glances between participants. As each presenter applies foundation and concealer to their white models, promoting the products they use as they go, a refrain echoes from the audience as participants take turns to ask: "E para pele negra?" (And for Black skin?).

Priscila later addresses this question of narrowing the nose in her salon during a professional makeup course that she offers to community residents. The course includes eight lessons, each one focused on a different aspect of makeup, all of which are designed to both promote technique and to "professionalize" students wishing to make a career in maquiagem. Two students, Bruna and Joana, have enrolled in this course, and Priscila has invited me to participate as well, pushing me to develop my own embodied familiarity with makeup application. We have already spent hours practicing makeup styles for daytime, for nighttime, and learning about basic relationships of primary, secondary, and tertiary colors in a lesson on "colormetrics." This evening we focus on pele negra, Black skin, and hone our techniques on different models. When we come to the nose, Priscila deliberately prefaces her method with a disclaimer before proceeding to narrow the nose of my model, Larissa. ${ }^{8}$

Priscila: You always have to be very careful here ... it's a cultural thing, you always have to ask. There are some people who will be offended if you narrow their nose without asking, so I always ask, and almost always, everyone wants me to narrow their nose anyway. But some girls get offended, like Black girls that are . . . how do you say it? Black ...

Joana: Activist?

Priscila: Yes, like a Black activist type. They might get offended, because you're implying a certain beauty standard that they disagree with ...

We might interpret this scene as an embodiment of the racial inferiority complexes discussed by Frantz Fanon (1967). In his analysis, internalized racism 
drives the individual pursuit of Black transformation, the donning of a "white mask" through the acquisition of status symbols like education or mastery of white language. Makeup techniques that alter racialized signs of the body, such as the nose, could thus be thought of as crude, physical manifestations of Fanon's metaphoric white mask. But such an interpretation would imply that Priscila and her students are blind to such issues, and have been thoroughly mystified by contemporary, racialized beauty standards.

In fact, Priscila is hyperaware of the racial politics of her makeup, and tells me later that she's really responding to demand from her clients. While one might suggest, and likely find currency in the argument that the beauty industry in Brazil shapes and mystifies racism, that line of argument alone paints Priscila's clients as passive consumers who adopt hegemonic aesthetic ideals without question. This is not the case. In fact, attempts to explain aesthetic trends on the periphery as either (1) entirely shaped by dominant aesthetic and racial sensibilities, or (2) expressions of resistance to those sensibilities, are equally incomplete. Alvaro Jarrín (2017) has addressed the structure-versus-agency debate in his work on aesthetics in Brazil, and found fertile ground in the affective, visceral allure of beauty in driving aesthetic decision-making. ${ }^{9}$ He suggests that rather than assessing beauty as shaped entirely by hegemonic norms, or, conversely, interpreting aesthetic decisions as conscientious reactions to those norms, we should examine the lived, sensorial experience of being regarded as beautiful. A similar phenomenological approach to beauty, rather than false consciousness - and I would extend that to include the sensation not just of beauty but also of transformation - drives the aesthetic impulses documented in this article. I do not mean to suggest that an experience of beauty is in any way divorced from experiences of race, but to indicate that aesthetic decisions are rarely either entirely agentive or mystified.

At the same time, to cast engagements with beauty as only phenomenological misses the degree to which makeup application, as witnessed above, continues to factor into ongoing constructions of race. As a practice of inchoate signs, makeup operates, at least in part, on a complementary and nondiscursive semiotic register that often guides practitioners into more explicit, habituated conversations about the politics of race. In referring to these aesthetic practices as nondiscursive, I do not mean to suggest that makeup is pre-semiotic or somehow devoid of meaning. Rather, I contend that makeup often conveys meaning through material forms that may be emergent within discourse but that need not be represented in language. I place my focus here on the first two registers within each of Charles Sanders Peirce's (1955) three trichotomies of the sign, and specifically, on those registers 
whose interpretants do not rely on habit or convention. ${ }^{10}$ Makeup is ideal for examining these more sensuous, material, and nonsymbolic aspects of the semiotic process - what I lump together as "nondiscursive" but what in fact includes signs that are simply sheer qualities or embodiments of quality (Munn 1986; Cavanaugh 2009), as well as signs that mimic and/or point to their objects (Keane 2005; Mendoza-Denton 2007; Manning 2012). That is because makeup, like the icon and index more broadly, is fleeting and latent with possibility, and as such often resists taking solid shape within language and discourse. Priscila's lesson on makeup and noses proves emblematic of this relation between semiotic registers, since in manipulating faces with makeup, she also constantly reshapes the connection between aesthetics and race. Indeed, applications of makeup — shaped by desire, an affection for transformation, or in pursuit of a yet-to-be-defined image of beauty- often occur at levels of semiotic engagement that are prior to, or below, broader, explicit discourses about race. Again, just because aspects of makeup may be nondiscursive, it does not mean that the signs that constitute these aesthetic practices remain insulated from politics or ideology, or that such practices are immune to the dynamics of race more broadly. Rather, the nondiscursive, sensuous, and material properties of makeup often rub up against habituated ways of thinking about race, and in so doing, they create tensions, ambiguities, racial "reorderings," and, perhaps, momentary resolutions.

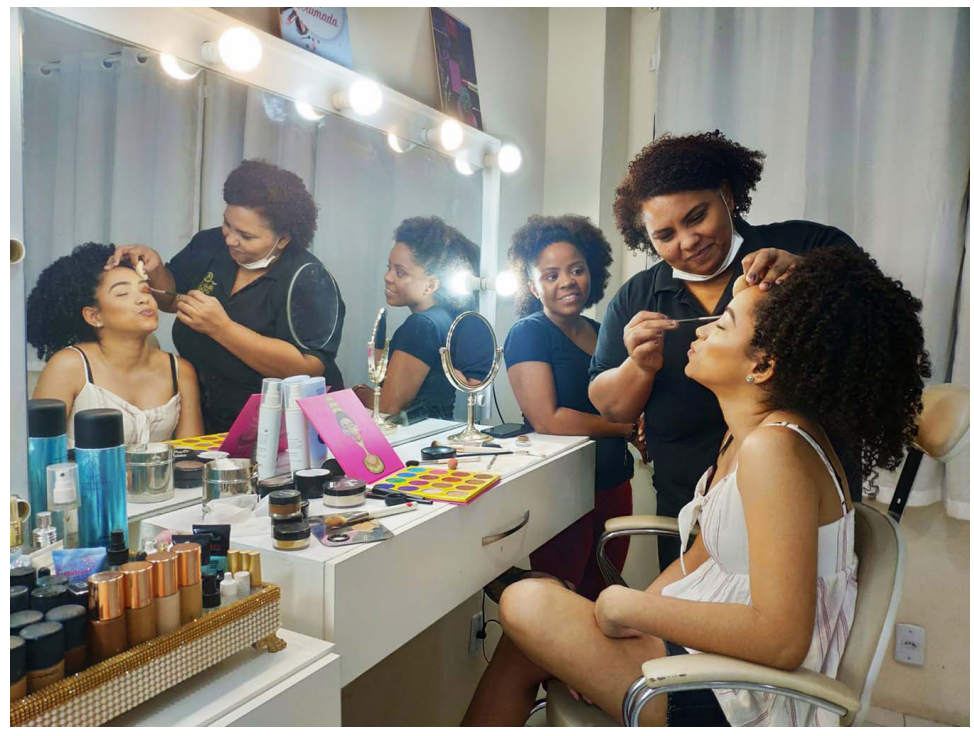

Figure 2. Priscila demonstrates an eye-shadow technique during a makeup professionalization course. Photo by Samuel Elliott Novacich. 
Racial thinking in Brazil, like elsewhere, has always been muddled and fragmentary yet ideologically convincing - and has therefore often appeared natural and without contradiction. From Gilberto Freyre's (1933) epic Casa-Grande e Senzala, which painted a romantic portrait of settler colonialism and slavocracy, to the eugenic underpinnings of "whitening" (Skidmore 1974) and, later, the demystification of "racial democracy" (Fernandes 1965), descriptions of racial exceptionalism have peppered academic work produced within and beyond Brazil. But it is important to problematize each of these interventions and associated concepts, and recognize that they tend to cohere and smooth over what are otherwise incongruous strands of thought. Paulina Alberto has described the twentieth-century shift from "racial democracy" to the "myth of racial democracy" in historiographical terms, first questioning the solidity of "racial democracy" itself (Alberto 2012). Rather than accepting it as a stable set of ideas - typically attributed to Freyre and glossed as harmony resulting from centuries of miscegenation-Alberto discusses "racial democracy" as a shifting identifier that reflects the specific social and political concerns of its time. She asserts that academics and Black intellectuals of the mid-twentieth century were not blind to the implications of Freyre's legacy, but rather acutely aware of the way their engagements with racial democracy rested within shifting conversations about race. Perhaps the most significant intervention in Alberto's work is to point out that race in Brazil has always been ambiguous and filled with internal contradictions. Indeed, conversations about race in Brazil have been slow, nonlinear, and riddled with contention, and they make up an ideologically heterogeneous landscape populated with ideas about color, phenotype, and the body. Within this muddled landscape there are those, like Manuela and even the aforementioned "Black activists," for whom surface aesthetics are a mark of identification and a reflection of essential belonging. Their faces may be beautified, but they must not contradict who they are "inside." But for others, the surface of the body offers less a window to the soul than it provides a canvas on which to paint and transform.

Livio Sansone (2003) has isolated a segment of this racial landscape and called it "race without ethnicity," the idea that in Brazil race is pinned to the surface of the body, rather than something that speaks to lineage or "corporate unity." And although Sansone's arguments resonate with a large body of ethnographic data and certainly explain the limitations in Black political movements of the twentieth century, he approaches race in Brazil as a stable object of study. This ignores the ruptures and contradictions in racial thought that permeate contemporary Brazil. These "dispersions" might include thinkers like Abdias do Nascimento, who 
founded the Teatro Experimental do Negro (TEN; Black Experimental Theater) in 1944 and who wrote against the grain of mainstream racial thought for decades. Indeed, his works anticipated a wave of new, earnest conversations about race that would accompany the transition from military to democratic rule in the 1970s and 1980s and include considerations for hypo-descent, origin, and DNA (Wade 2017). This also marked an important moment during which the bodily surface came within conceptual reach of ideas about internal difference. In 1990s Bahia, for example, Black residents of Salvador — attuned to the pluralities in racial thought outlined above — drew important links between the bodily surface and ideas of internal difference to navigate the objectification of their historically Afro-Brazilian neighborhoods (Collins 2015). And yet, an interpretive logic that takes us from the material surface of the body to ideas about soul and essence in Brail today is far from consistent, and in fact such a racial metaphysics remains remarkably uneven. Rather, the racial hermeneutics and their inconsistencies hitherto described in this article are far more akin to the fractured condition of Oscar Wilde's title character, Dorian Gray. That is to say, the bodily surface is sporadically untethered from all that has come to be associated with interiority, including racial and gendered essence, soul and sin.

There are moments when aesthetic signs like skin tone and the width of one's nose point to race, and these moments are further complicated when we recognize the plurality of racial constructions that refer to race as both sets of internal qualities and expressions of outward appearance. But there are also moments when (and people for whom) these same signs skirt direct associations with race, instead approaching it indirectly, via affective qualities like beauty and desire (Ochs 1992). How is it that the same aesthetic signs can mean so many different things? One possible answer resides in "regimes of truth," which, as Ann Stoler (1997, 186) has explained, compel us to interpret the "relationship between the seen and the unseen" (see also Foucault 1980). She argues that according to one set of assumptions, "the 'truth' of race is understood as grounded in somatically observable, dependable differences; in the other, the 'truth' of racial membership is not visually secured at all. Surface perceptions are unreliable and membership is dependent on privileged knowledge of 'hidden properties' of human kinds, of those secreted in their depths" (Stoler 1997, 86). Such insights compel us to examine these disparities between the "seen" and the "unseen,"11 the tensions and apparent contradictions in racisms through history, and ultimately assert, as Stoler (1997, 187) suggests, that "the ambiguity of those sets of relationships between the somatic and the inner self, the phenotype and the genotype, pigment shade 
and psychological sensibility are not slips in, or obstacles to, racial thinking but rather conditions for its proliferation and possibility." The power of racisms - variable across time and space but with obvious consistencies throughout - resides in their capacity to shift, to find new footings in disparate regimes of truth. The apparently contradictory aesthetic and racial logics of this article, and indexical oscillations, are not signs of immediate shifts in racial thought or indications of a soon-to-be-post-racial Brazil, but rather symptoms of what we must understand race and racisms in general to be: fluid yet fragile arrays of indexical signs existing in internal tension with one another.

The internal incoherence of certain discourses is precisely why the ethnographic material presented in this article points to a certain degree of play, ambiguity, and even contradiction when measured against what we think we know about race in Brazil. Such an analysis becomes especially contentious when race and racial discourse are taken as stable objects. In writing against race as a solid thing, I have attempted to explore how race mutates through an ongoing interplay between discourse (or ideology) and what I have termed "nondiscursive" registers. Back in Priscila's studio, this interplay is clear. As she teaches her students to narrow their clients' noses, we see makeup, as a material, sensorial process, and language, as metacommentary on makeup application, working side by side. Priscila cautions her workshop participants to be "very careful" in approaching their clients' noses, signaling her awareness of an important transformation in the relation of beauty standards to racial discourses of the past thirty years. ${ }^{12}$ At the level of discourse, Priscila and her clients appear to be uniformly aware of the ways in which racial politics shape aesthetics (Pinho 2007; Mizrahi 2012). As the exchange between Priscila and her students makes clear-and as the glances stolen between workshop participants first introduced in this article's opening vignette confirm - most artists are keenly aware of the impact of race on their work. And yet, makeup artists and their clients do not simply react to existing racial ideologies and adapt their makeup practice in relation to such concerns. As Priscila continues our lesson, stepping in to demonstrate a new technique on one of our models or to correct a mistake, she engages with both race and aesthetics on a distinct semiotic register. As described above, this complementary process - nondiscursive yet fundamental to ongoing constructions of race-is constituted by affective and aesthetic impulses whose particular, often untheorized emergence exists in contrast to the cognized, habitual, and discursive register that helps make clear to participants how race works in their daily lives (McCallum 2005; Caldwell 2007; Roth-Gordon 2017). Guided by material sensation and the pursuit of aes- 
thetic qualities as ends in and of themselves, these novel, aesthetic movements - in contrast to the "natural" counteraesthetics that often reify racial essentialism — often progress in tension with racial discourse to be negotiated piecemeal through everyday practice.

Aesthetic practices of beautification, “making up," and covering up in Rio de Janeiro are what may be regarded as experimental, nondiscursive moments in the production of yet-to-be-actualized ideas about race. But rather than thinking of such moments as exceptional, these exploratory, sensuous aesthetics are in fact mundane. They explain why habituated political discourses are never entirely smooth "below the surface." ${ }^{13}$ Instead, discourses are often internally ambiguous, and cobble together coherence from relative epistemic disorder. As such, we may also think of nondiscursive aesthetic practices as strands of material disorder, strands latent with possibility but often incongruous with existing ideas about race. And one such material strand, the aesthetic decoupling of the bodily surface from notions of interiority, while full of apparent contradictions, in fact highlights the persistence of race, revealing, when we look “deeper," overlapping regimes of truth, muddled racial hermeneutics, and openings for new aesthetic possibilities.

\section{CONCLUSION}

In my discussions with makeup artists and their clients, we rarely spoke directly about race as it related to aesthetic decisions. To be clear, this does not mean to suggest the avoidance of conversations about race or personal experiences. If anything, quite the opposite occurred, and questions of race and class continuously crept into conversation as explanations for the marked inequalities that defined everyday life for my interlocutors (Smith 2016). There are also surely clients out there who narrow their noses, style their hair, or wear specific clothing to make explicit statements about their own racial identities. But the styles that Priscila's makeup clients requested seemed to have little to do with masking or altering their Blackness, or even "Blackness" as an emergent politics of mutating conditions. Indeed, within these aesthetic contexts, ${ }^{14}$ the surface of the body was not only regarded as an index of ethnicity but it also became an icon of color, desire, and beauty. That is to say, the color of one's eye shadow or lipstick, or the contouring of a nose, did not point consistently to any single referent. Instead, these aesthetic details were relished as the embodiments of pleasure and desire, the phenomenology of beauty described by Alvaro Jarrín (2017). Makeup — both physically and metaphorically skin deep_often lives and dies on the surface of the body, where it is frequently severed from ideas about genealogically racialized 
difference. And yet paradoxically, applications of makeup prove critical to ongoing constructions of race. Through the sensuous pursuit of beauty, pleasure, and transformation, Priscila and her clients continually reshape their faces in ways that compel subsequent racial reckonings, shifting what we think we know about race and weakening the soft ground on which such knowledge sits. Makeup, though frequently untethered from considerations of race, nevertheless shapes constructions of race — not by pointing to insides, but by adding layers to the surface of the body.

The aesthetic practices described throughout this article might be viewed as terribly contradictory when set against what is known about dominant constructions of race in Brazil. And while emphasizing internal contradiction proves delicate - and might serve as potential analytical bait, given the extent to which race in Brazil is often oversimplified as "mixed and complex," in contradistinction to the assumed simplicity of race in the United States - it bears repeating that race is continuously changing shape, and not just in Brazil. Indeed, I have actively avoided trying to reconcile the above aesthetic practices with any single understanding of race or bodily metaphysics. But the question that remains - and one that will continue to shape the lives of Afro-Brazilians in Rio's northern suburbs and throughout Brazil - is to what extent, and in relation to what sorts of everyday practices, phenotype and skin color gain or lose semiotic potency within muddled, constantly shifting racial logics. ${ }^{15}$ Certainly, things like skin color, noses, and hair do not simply disappear. Indeed, color remains as an imperfect sign in relation to an imperfect hermeneutics of the body. Ideas about race in Brazil - like discursive constructions everywhere - are in transition, mixed and contradictory, and as such, different signs of race gain prominence in specific contexts. That statement in itself is not innovative. What is, I contend, is the notion that the surface of the body, where color and phenotype reside, is both linked to and independent from ideas about our bodily interiors.

Indeed, surfaces can be dislodged from the body and its moral underpinnings through a "doubling" of the skin — and self_—as portrait. As race and racisms continue to shape-shift, aesthetic openings, and even moments of pleasure, occur. They are what allow Priscilla to narrow a nose while simultaneously promoting beleza negra on models who wear earrings imprinted with the words " $100 \%$ NEGRA." Who makes the most of these aesthetic openings remains to be seen. Perhaps a good place to look is in the makeup salons of Rio de Janeiro's urban periphery. 


\section{ABSTRACT}

This article examines applications of bright, eye-catching makeup on the periphery of Rio de Janeiro, Brazil. Tracking the aesthetic decisions of makeup artists and their clients, I analyze how colorful manipulations of the bodily surface relate to local constructions of race. But the bodily surface does not simply reflect established and conventional understandings of race, nor are the aesthetics described herein merely symbolic of assumptions of difference. Instead, the aesthetic practices portrayed in this article may also be regarded as experimental, "nondiscursive" moments - operating on a complementary semiotic register - in the production of yet-to-be actualized ideas about race and being. This research shows how makeup practices often disrupt the aesthetic and conceptual links that tie insides to outsides, essences and souls to physical appearance, and in so doing chip away at the foundations on which race in Brazil has historically been built. Through sixteen months of ethnographic fieldwork (2019-2020) in Rio's northern suburbs, I observed as disparate aesthetic practices - namely, beautification and transformation - merged with eclectic understandings of the body and notions of being. Through these alternating lenses, makeup enthusiasts often interpreted material signs of the body as pointing to categorical constructions of race, on the one hand, and to beauty, sex, and desire, on the other. These semiotic oscillations and their interpretations often stood in conflict with established racial discourses, and yet rather than being exceptional, I argue that such exploratory, sensuous aesthetics are in fact mundane. Taking as a starting point the understanding that racial discourse in Brazil, as elsewhere, is internally ambiguous and rife with epistemic conflict, this article describes nondiscursive aesthetic practices as strands of material disorder-latent with possibility but often incongruous with what we think we know about race — working to forge novel understandings of race, beauty, and the body. [makeup; aesthetics; race; semiotics; the face; the body]

\section{RESUMO}

Este artigo examina o uso de maquiagem brilhante e chamativa na periferia do Rio de Janeiro, Brasil. Acompanhando as decisões estéticas de maquiadores e seus clientes, analiso como as manipulações coloridas da superfície do corpo se relacionam com as construções locais de raça. Mas a superfície corporal não reflete simplesmente entendimentos estabelecidos e convencionais de raça, nem são as estéticas descritas aqui meramente simbólicas de suposições de diferença. Em vez disso, as práticas estéticas retratadas neste artigo também podem ser consideradas como momentos experimentais, "não discursivos" - operando em um registro semiótico complementar - na produção de ideias a serem ainda atualizadas sobre raça e ser. Esta pesquisa mostra como as práticas de maquiagem muitas vezes interrompem os vínculos estéticos e conceituais que unem o interior ao exterior, as essências e as almas à aparência física e, ao fazer isso, abalam os próprios alicerces sobre os quais a raça no Brasil foi historicamente construída. Ao longo de 16 meses de trabalho de campo etnográfico (2019-2020) na zona norte do Rio, observei como práticas estéticas díspares - isto 
é, embelezamento e transformação - amalgamaram com compreensões ecléticas do corpo e noções de ser. Através dessas lentes alternadas, os entusiastas da maquiagem frequentemente interpretavam os sinais materiais do corpo como apontando para construções categóricas de raça, de um lado, e, para beleza, sexo e desejo, de outro. Essas oscilações semióticas e suas interpretações estavam frequentemente em conflito com os discursos raciais estabelecidos e, no entanto, ao invés de serem excepcionais, eu argumento que essas estéticas exploratórias e sensuais são, na verdade, banais. Tomando como ponto de partida o entendimento de que o discurso racial no Brasil, como em outros lugares, é internamente ambíguo e repleto de conflito epistêmico, este artigo descreve práticas estéticas "não discursivas" como fios de desordem material - latentes com possibilidades, mas muitas vezes incongruentes com o que achamos que sabemos sobre raça - trabalhando para forjar novas compreensões de raça, beleza e corpo. [maquiagem; estética; raça; semiótica; rosto; corpo]

\section{NOTES}

Acknowledgments This article benefited greatly from time and resources provided by the CUNY Graduate Center anthropology program, and in particular from conversations with Jillian Cavanaugh, Marc Edelman, Julie Skurski, and Karen Strassler. John Collins has exemplified what it means to be a great academic advisor, and his influence in these pages is clear. Thanks also to Jim Green for his long-standing support, to Adriana Facina and the Universidade Federal do Rio de Janeiro, to Alessandro Angelini, Isabella Benevides, Victor Carvalho, Nicole Labruto, Felippe Marchiori, and Mylene Mizrahi, to my graduate colleagues Angela Crumdy, Stephanie Love, Yasemin Ozer, Christopher Parisano, and Paloma Rodrigo Gonzales, and to the members of my writing seminar who offered helpful comments on this piece. This research was made possible by funding from a Fulbright-Hays DDRA, as well as the Early Research Initiative, and the Doctoral Student Research Grant and Urban Studies programs at the CUNY Graduate Center. Many thanks are also owed to Cultural Anthropology editor, Brad Weiss, and publications manager, Jessica Lockrem, as well as to the anonymous reviewers who provided constructive comments and guidance. Of course, I cannot overstate my indebtedness to Priscila and the many makeup enthusiasts who welcomed me into their spaces and shared their passions for beauty. Finally, my greatest acknowledgment goes to Candy Pilar Godoy for her continued support, partnership, and insight, and to our families, both human and otherwise.

1. Most of the names in this article have been changed to protect the privacy of participants. I have decided to retain the actual names of a select few makeup artists and beauticians who may be regarded as public figures.

2. Of course, Wilde's tale is a cautionary one in that the rupture of outside from inside results in moral failing, as Gray's portrait doesn't just age, but becomes rotten, reflecting his debauchery. Wilde thus captures the double nature of the portrait - and specifically, of the face- by suggesting that while appearances may be superficial, they nevertheless reveal the morality of our acts.

3. One interesting comparison is with Marilyn Strathern's analysis of self-decoration practices in Papua New Guinea, which she argues involve a radical departure from Western cosmologies of body and soul. Although a relationship between interiority and the bodily surface persists - much as it does in Rio - Strathern argues that for Hageners, the hermeneutics of surface to depth is inverted. Body decoration does not concern superficial artifice, but rather a physical and aesthetic demonstration of inner strength. The decorated body thus becomes a window, revealing one's power, while the undec- 
orated, naked body acts more as a mask, concealing one's potential (or weakness) from others (M. Strathern 1979).

4. A note on research methods: I have known Priscila for about ten years, meeting her for the first time when she still worked in the kitchen of her cousin's restaurant in the northern-zone favela known as Mangueira. At the time, Priscila was new to makeup, but devoted hours each evening to honing her craft, watching endless YouTube video tutorials and starting to attend to clients in her small, one-bedroom apartment above the restaurant. She welcomed me into her world with open arms and helped explain the presence of her white, heterosexual North American friend as I slowly became a fixture in her salon.

5. Although her comments hinted at a general discomfort with gender nonconformity, I did not interpret this specific phrasing as being explicitly transphobic. In this exchange, Manuela uses the English word drag, in what to me seemed a deliberate word choice over the Portuguese travestí, or the term most recently adopted in Brazil, trans. I did not, however, push Manuela on her word choice, electing rather to let her speak freely and without interruption, and am now compelled to assume that her intended referent was indeed "men doing drag."

6. Or, for another example, consider the "mask of Zorro," which is less a full facial mask than a narrow strip of black cloth concealing a small area of the face around the eyes. Or, for an even more extreme example, and maintaining the hero theme, we have the almost absurd transformation of Clark Kent into Superman, which involves removing only a pair of glasses.

7. This may or may not also be a reference to Beyoncé and emblematic of her transnational aesthetic reach. The quotation "I woke up like this," comes from Beyoncé's 2013 song “***Flawless," which features a sample from a speech delivered by Chimamanda Ngozi Adichie about female empowerment and gender equality. About halfway through the song, Beyoncé begins chanting, "I woke up like this, I woke up like this . . flawless ...." in what seems to be at first irony - akin to the invocations of Priscila's clients - given the singer's perfectly applied dark lipstick and eye shadow in the music video. But in a subsequent interview about the song, Beyoncé explained that she had woken up agitated, and went to the studio with the lyrics already in her head. She further elaborated that "it was aggressive, it was angry, it wasn't the Beyoncé that wakes up every morning." "I woke up like this" might then refer to both outward physical appearance and one's emotional state, and so while the women in Priscila's studio exclaim "I woke up like this" with apparent irony, the expression may also be interpreted as referencing internal states like mood, emotions, or desire.

8. Priscila first applies a layer of illuminating concealer under the eyes that creeps up the sides of the nose at slight angles, leaving the negative space of an upside-down triangle extending from between the eyes down the bridge of the nose. She then uses dark contour - matching the shade used earlier on the cheeks - and applies this deliberately to both sides of the nose. Finally, she uses the tip of her ring finger - a finger strong enough to be precise and weak enough to not overblot - to lightly tap highlighter onto the end of the nose, using a small brush to blend the illumination without losing its focus at the tip of the nose.

9. Jarrín's (2017) actual analysis is a deft hedging of the heavy-handedness of his book title The Biopolitics of Beauty. He points to the limits of Foucauldian attitudes on beauty, asserting that such approaches generally regard bodies as passive canvases for society's biopolitical inscriptions. This is an argument made initially by Edmonds (2010), with whom Jarrín is in regular dialogue throughout the book. Jarrín critiques Edmonds for naively attributing an unbridled agency to his interlocutors, and for suggesting that beauty exists along an axis independent of wealth and yet acts as an unfettered engine of upward mobility.

10. Wishing to limit the degree to which this section is saturated in Peircean neologisms, I have condensed some terms into an umbrella of signs that I refer to as "nondiscursive." Peirce argues that signs may be divided into three trichotomies: first, according to the 
existential state of the sign itself; second, according to the relation of the sign and its object; and third, according to the relation of the sign and its interpretant. He defines an interpretant as that which is addressed by the sign, creating "in the mind of that person an equivalent sign, or perhaps a more developed sign" (Peirce 1955, 99).

11. I am intentionally wording the above intervention as "insight" to highlight the naturalization in language of an imagined divide between appearance/artifice/externalities and depth/truth/internalities, and the resultant implications for knowledge production.

12. I am referring here to an aesthetic shift that occurred in the $1990 \mathrm{~s}$, which might be contextualized by the "opening up" of the political landscape following decades of military rule (1964-1985). This political shift provided room for a surge in new social movements and, critically, reinvigorated conversations about race in Brazil. Patricia Pinho (2007) has referred to the aesthetic shift that emerged with these conversations as "Afro-Aesthetics"—noses deliberately not narrowed with makeup, Jamaican dreadlock-inspired hairstyles, and bright textiles - in the valorization of an aesthetic that ties the African diaspora together.

13. In referring to these moments as either "nondiscursive" or "habituated," I am calling attention again to Peirce's phenomenology of the sign, because I believe that such a theoretical parsing of racial constructions can only be achieved through reference to Peirce's semiotic categories. The former, which recognizes signs as material and operating beyond their conventional grounds - what he would call generalized or habituated - and instead according to their material qualities, may be understood as nondiscursive in that they communicate not according to convention, but, instead, according to material qualities of the sign.

14. As should be obvious at this point, aesthetic contexts in Rio de Janeiro are inseparable from political contexts, and following Ariella Azoulay's (2010) assertion that the separation of aesthetics from politics is a false distinction that ultimately derives from a misreading of Walter Benjamin's (1969 [1936]) “The Work of Art in the Age of Mechanical Reproduction," readers are invited to experiment by replacing each iteration of the word aesthetic in this article with political.

15. These practices must also be understood as existing within a context in which pushing back against muddled, constantly shifting racial landscapes has at times proven central to Black activism in Brazil. This held particularly true in the early 1990s, when activists launched a campaign to não deixe sua cor passar em branco (literally, "don't let your color pass for white," but used to mean "don't go overlooked”) for the 1991 census to encourage Afro-Brazilians to self-identify as negro.

\section{REFERENCES}

Alberto, Paulina L.

2012 "Of Sentiment, Science and Myth: Shifting Metaphors of Racial Inclusion in Twentieth-Century Brazil.” Social History 37, no. 3: 261-96. https://doi.org/10.10 80/03071022.2012.701052.

Azoulay, Ariella

2010 "Getting Rid of the Distinction between the Aesthetic and the Political." Theory, Culture and Society 27, no. 7/8: 239-62. https://doi.org/10.1177/0263276410384750.

Belting, Hans

2017 Face and Mask: A Double History. Princeton, N.J.: Princeton University Press. Benjamin, Walter

1969 "The Work of Art in the Age of Mechanical Reproduction." In Illuminations, edited by Hannah Arendt, translated by Harry Zohn, 217-51. New York: Schocken Books. Originally published in 1936.

Benson, Peter

2008 "El Campo: Faciality and Structural Violence in Farm Labor Camps." Cultural Anthropology 23, no. 4: 589-629. https://doi.org/10.1111/j.15481360.2008.00020.x. 
Caldwell, Kia Lilly

Cannell, Fenella

2007 Negras in Brazil: Re-envisioning Black Women, Citizenship, and the Politics of Identity. New Brunswick, N.J.: Rutgers University Press.

1999 Power and Intimacy in the Christian Philippines. Cambridge: Cambridge University Press.

Cavanaugh, Jillian R.

2009 Living Memory: The Social Aesthetics of Language in a Northern Italian Town. Hoboken,

Collins, John F. N.J.: Wiley-Blackwell.

2011 "Melted Gold and National Bodies: The Hermeneutics of Depth and the Value of History in Brazilian Racial Politics." American Ethnologist 38, no. 4: 683-700. https://doi.org/10.1111/j.1548-1425.2011.01330.x.

2015 Revolt of the Saints: Memory and Redemption in the Twilight of Brazilian Racial Democracy. Durham, N.C.: Duke University Press.

DeLanda, Manuel

2002 Intensive Science and Virtual Philosophy. New York: Continuum.

Deleuze, Gilles, and Félix Guattari

1987 A Thousand Plateaus: Capitalism and Schizophrenia. Translated by Brian Massumi. Minneapolis: University of Minnesota Press.

Edmonds, Alexander

2010 Pretty Modern: Beauty, Sex, and Plastic Surgery in Brazil. Durham, N.C.: Duke University Press.

Fanon, Frantz

1967 Black Skin, White Masks. Translated by Richard Philcox. New York: Grove.

Fernandes, Florestan

1965 A integração do negro na sociedade de classes: O legado da "raca branca." São Paulo: Dominus Ed.

Foucault, Michel

1980 "Truth and Power." In Power/Knowledge: Selected Interviews and Other Writings, 1972-1977, edited by Colin Gordon, translated by Colin Gordon, Leo Marshall, John Mepham, and Kate Soper, 109-33. New York: Pantheon.

Freyre, Gilberto

1933 Casa-Grande e senzala: Formação da família brasileira sob o regime de economia patriarchal. Rio de Janeiro: Maia and Schmidt.

Galton, Francis

1879 "Generic Images." Proceedings of the Royal Institution 9: 161-70.

Goldsby, Jackie

1993 "Queens of Language: Paris is Burning." In Queer Looks: Perspectives on Lesbian and Gay Film and Video, edited by Martha Gever, John Greyson, and Pratibha Parmar, 108-15. New York: Routledge.

Guimarães, Antonio Sérgio Alfredo

2002 Classes, raças e democracia. São Paulo: Editora 34.

Harris, Marvin, and Conrad Kottak

1963 "The Structural Significance of Brazilian Racial Categories." Sociologia 25: 203-9.

Jablonski, Nina G.

2006 Skin: A Natural History. Berkeley: University of California Press.

Jarrín, Alvaro

2017 The Biopolitics of Beauty: Cosmetic Citizenship and Affective Capital in Brazil. Berkeley:

Kalba, Laura Anne

University of California Press.

2017 Color in the Age of Impressionism: Commerce, Technology, and Art. University Park, Pa.:

Penn State University Press. 
Keane, Webb

2005 "Signs Are Not the Garb of Meaning: On the Social Analysis of Material Things." In Materiality, edited by Daniel Miller, 182-205. Durham, N.C.: Duke University Press.

Lévi-Strauss, Claude

1972 Tristes Tropiques. Translated by John Russel. New York: Atheneum. Originally published in 1955.

Lombroso, Gina, and Cesare Lombroso

1911 Criminal Man: According to the Classification of Cesare Lombroso. New York: Knickerbocker.

Manning, Paul

2012 Semiotics of Drink and Drinking. New York: Bloomsbury.

McCallum, Cecilia

2005 "Racialized Bodies, Naturalized Classes: Moving through the City of Salvador da Bahia." American Ethnologist 32, no. 1: 100-17. https://doi.org/10.1525/ ae.2005.32.1.100.

Mendoza-Denton, Norma

2007 Homegirls: Language and Cultural Practice Among Latina Youth Gangs. Oxford: Blackwell.

Miller, Daniel

2010 Stuff. Cambridge, Mass.: Polity.

Mizrahi, Mylene

2012 "Cabelos como extensões: Relações protéticas, materialidade e agência na estética funk carioca." Textos escolhidos de cultura e arte populares 9, no. 2: 137-57. http://

Munn, Nancy D. dx.doi.org/10.12957/tecap.2012.10265.

1986 The Fame of Gawa: A Symbolic Study of Value Transformation in a Massim Society. Cambridge: Cambridge University Press.

Nogueira, Oracy

2007 "Preconceito racial de marca e preconceito racial de origem: Sugestão de um quadro de referência para a interpretação do material sobre relações raciais no Brasil.” Tempo Social 19, no. 1: 287-308. https://doi.org/10.1590/S010320702007000100015 . Originally published in 1954.

Ochs, Elinor

1992 "Indexing Gender." In Rethinking Context: Language as an Interactive Phenomenon, edited by Alessandro Duranti and Charles Goodwin, 335-58. Cambridge: Cambridge University Press.

Peirce, Charles Sanders

1955 Philosophical Writings of Peirce. Edited by Justus Buchler. New York: Dover.

Pinho, Patricia

2007 “Afro-Aesthetics in Brazil." In Beautiful/Ugly: African and Diaspora Aesthetics, edited Pollock, Donald by Sarah Nuttall, 266-89. Durham, N.C.: Duke University Press.

1995 "Masks and the Semiotics of Identity." Journal of the Royal Anthropological Institute

Poole, Deborah 1, no. 3: 581-97. https://doi.org/10.2307/3034576.

1997 Vision, Race, and Modernity: A Visual Economy of the Andean Image World. Princeton,

Rancière, Jacques N.J.: Princeton University Press.

2004 The Politics of Aesthetics: The Distribution of the Sensible. London: Continuum.

Roth-Gordon, Jennifer

2017 Race and the Brazilian Body: Blackness, Whiteness, and Everyday Language in Rio de Janeiro. Oakland: University of California Press. 
Sansone, Livio

2003 Blackness without Ethnicity: Constructing Race in Brazil. New York: Palgrave Macmillan.

Sekula, Allan

1986 "The Body and the Archive." October 39: 3-64. https://doi.org/10.2307/778312.

Sheriff, Robin E.

2001 Dreaming Equality: Color, Race, and Racism in Urban Brazil. New Brunswick, N.J.: Rutgers University Press.

Siegel, James T.

1999 "Georg Simmel Reappears: 'The Aesthetic Significance of the Face." Diacritics 29, no. 2: 100-13. https://www.jstor.org/stable/1566457.

Skidmore, Thomas E.

1974 Black into White: Race and Nationality in Brazilian Thought. New York: Oxford University Press.

Smith, Christen A.

2016 Afro-Paradise: Blackness, Violence, and Performance in Brazil. Champaign: University of Illinois Press.

Sontag, Susan

1966 "Notes on 'Camp.” In Against Interpretation and Other Essays, 275-92. New York: Picador.

Stoler, Ann Laura

1997 "Racial Histories and Their Regimes of Truth." Political Power and Social Theory 11: $183-255$.

2002 "Developing Historical Negatives: Race and the (Modernist) Visions of a Colonial State." In From the Margins: Historical Anthropology and Its Futures, edited by Brian Keith Axel, 156-88. Durham, N.C.: Duke University Press.

Strassler, Karen

2010 Refracted Visions: Popular Photography and National Modernity in Java. Durham, N.C.: Duke University Press.

Strathern, Andrew

1975 "Why Is Shame on the Skin?" Ethnology 14, no. 4: 347-56. https://doi. org/10.2307/3773236.

Strathern, Marilyn

1979 “The Self in Self Decoration.” Oceania 49, no. 4: 241-57. https://doi. org/10.1002/j.1834-4461.1979.tb01915.x.

Van de Port, Mattijs

2012 "Genuinely Made Up: Camp, Baroque, and Other Denaturalizing Aesthetics in the Cultural Production of the Real." Journal of the Royal Anthropological Institute 18, no. 4: 864-83. https://doi.org/10.1111/j.1467-9655.2012.01796.x.

Viveiros de Castro, Eduardo

1998 "Cosmological Deixis and Amerindian Perspectivism." Journal of the Royal Anthropological Institute 4, no. 3: 469-88. https://doi.org/10.2307/3034157.

Wade, Peter

2017 Degrees of Mixture, Degrees of Freedom: Genomics, Multiculturalism, and Race in Latin America. Durham, N.C.: Duke University Press.

Wilde, Oscar

1962 The Picture of Dorian Gray and Selected Stories. New York: New American Library. Originally published in 1890 . 